Instructions for authors, subscriptions and further details:

\title{
http://mcs.hipatiapress.com
}

\section{Hombres en Movimiento: Masculinidades Españolas en los Exilios y Emigraciones}

Maria del Mar Ramis ${ }^{1}$

1) Universidad de Barcelona, Spain

Date of publication: February $21^{\text {th }}, 2019$

Edition period: February 2019-June 2019

To cite this article: Ramis, M. (2019). Hombres en movimiento:

Masculinidades Españolas en los exilios y emigraciones [Review of the book]. Masculinities and Social Change 8(1), 116-117. doi:

10.17583/MCS.2019.4097

To link this article: http://dx.doi.org/10.4471/MCS.2019.4097

\section{PLEASE SCROLL DOWN FOR ARTICLE}

The terms and conditions of use are related to the Open Journal System and to Creative Commons Attribution License (CC-BY). 
MCS - Masculinities and Social Change Vol. 8 No. 1 February 2019 pp. 116-117

\section{Reviews (II)}

González-Allende, I. (2018). Hombres en movimiento: Masculinidades españolas en los exilios y emigraciones, 1939-1999. West Lafayete, Indiana: Purdue University Press.

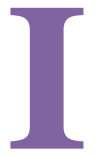

ker González-Allende, profesor en la Universidad de NebraskaLincoln, en este libro hace un análisis en profundidad de cómo afecta el exilio a diferentes personalidades masculinas de la historia de España. De esta forma se introducen algunos relatos biográficos de hombres que han construido su identidad determinada por procesos de exilio. En este sentido, es interesante observar como GonzálezAllende establece una diferenciación por tipologías de exilio, como por ejemplo el exilio por razones de orientación sexual.

En el libro se articula una combinación muy interesante entre análisis biográfico y revisión de la literatura científica sobre masculinidades. Se hace referencia por ejemplo a autores y autoras como Gilmore, Kimmel, Pease, Chodorow para referirse a construcciones teóricas que están directamente relacionadas con la vida de los hombres que se describen en el libro. Uno de los conceptos que emergen en el estudio es la figura del "breadwinner" que se distingue como aquel tipo ideal de hombre que existía en la España de la guerra cívil y la postguerra. Para González-Allende el proceso de emigración en hombres heterosexuales incide en este modelo, sobretodo porque su función principal se pone en peligro.

En los diferentes capítulos que configuran el libro González-Allende nos abre la puerta a la vida de personajes que han tenido su protagonismo en la cultura española, como por ejemplo es el caso de Luis de Castresana. El periodista, escritor y pintor basco formó parte del programa de "niños de la guerra" que tuvieron que vivir en otros países por motivos políticos. Aquí resulta interesante observar como dicho destierro tiene un efecto muy directo

2019 Hipatia Press

ISSN: 2014-3605

DOI: $10.17583 / \mathrm{MCS} .2019 .4097$ 
en su masculinidad ya que directamente marca la construcción de su identidad durante su infancia y adolescencia. En este capítol también se hace referencia a la metáfora de hombre árbol que Castresana utiliza en alguna de sus obras.

Otros relatos biográficos también muestran datos interesantes sobre la vida de hombres con otros motivos de exilio, como es el caso del poeta y ensayista Juan Gil-Albert. Él se exilia en Argentina y González-Allende subraya, entre otros aspectos, como se convierte en un los primeros autores en promocionar su interés por el ocio y su carácter hedonista. De forma paralela también se explicita la figura del escrito catalán Terenci Moix, al que se le califica como "el hombre onanista". De Moix se pone de relieve una de sus principales obras, "Extraños en el paraíso", la cual tiene connotaciones autobiográficas. Para hablar de Moix, González-Allende hace referencia a la vida del escritor en los años 60 en París y de sus experiencias sexuales y profesionales.

Podemos constatar que el libro representa una aportación a tener muy en cuenta en los estudios sobre masculinidad en España, aportando conocimiento interesante sobre el impacto del exilio en diferentes figuras masculinas.

Maria del Mar Ramis, Universidad de Barcelona. mimarramis@ub.edu 